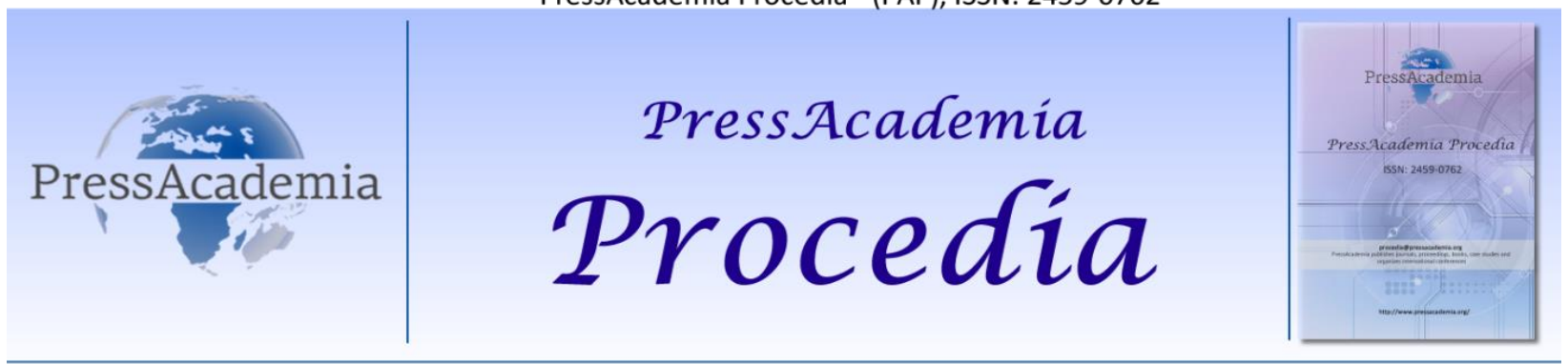

2nd World Conference on Technology, Innovation and Entrepreneurship

May 12-14, 2017, Istanbul, Turkey. Edited by Sefer Şener

\title{
SECTORAL DEVELOPMENT OF ICT FOR CARE
}

\author{
DOI: 10.17261/Pressacademia.2017.556 \\ PAP-WCTIE-V.4-2017(48)-p.369-374
}

\section{Guher Can Vural ${ }^{1}$, Hatice Reyhan Ozgobek ${ }^{2}$}

${ }^{1}$ Republic of Turkey Ministry of Family and Social Policies. guher.vural@aile.gov.tr

${ }^{2}$ Republic of Turkey Ministry of Family and Social Policies. reyhan.ozgobek@aile.gov.tr

\section{ABSTRACT}

Because of disability and or aging or illness people need long term care services in specific part of their life. Health and social care burden is increasing day by day in the world and our country. These services are home care, daily care, residental care, nursing home and paliative care services. These services are provided elderly people by formal and informal caregivers. Both burden of care and cost of care is increasing because of growing population of World. For this reason, using ICT technologies in care services is an important issue that cost of care services can minimize by using this technologies in care. To illustrate, following individual diabete rate by far, home security systems for Alzheimer, easy use technological products for elderly people. Because these products are popular for people who every aged and from different socio-cultural levels that they need them. In Turkey, there are techno-parks and entrepreneurs that work in ICT for care. Nowadays, little part of consumers use ICT for care in home care services\&mobile health care. In Turkey, families are caregivers in long term care services system mostly. Caring of disabled and elderly people is costly and hard. For increasing access of care services, families should be supported by ICT. Thus, existence structure will be sustainable care and health and social care expenditures will decrease. There is need of feasible study in ICT for care in our country. To sum up, using of ICT for care provide spreading of all care services models and relevant sectoral development.
\end{abstract}

Keywords: Disabled people, elderly people, sick, long-term care, information communication technology, sector JEL Codes: D83, N75, O38, 123

\section{INTRODUCTION}

In Turkey, General Directorate of Services for Persons with Disabilities and the Elderly that is the Government Coordinating Body have the task of preparing legislation on elderly services. Instead of public administration-based service provision; arrangements based on the protection of the elderly, uniform service provision for elderly people, intensive structure of elder society excluded from society; delivering service with local government, private sector and voluntary organization's collaboration and coordination, social responsibility development regulations for investment in individual capacity, delivering elderly services in line with needs, social environment and individual preferences are appropriate. Because of disability and/or aging or illness people need long term care services in specific part of their life. Health and social care burden is increasing day by day in the world and our country. These services are home care, daily care, residental care, nursing home and paliative care services. These services are provided elderly people by formal and informal caregivers. In Turkey, families are caregivers in long term care services system mostly. Ministry of Family and Social Policies deliver instituonal care services to both elderly and disabled people, informal care services as social aids. 541 thousand people benefit from social aids because of their disability (http://eyh.aile.gov.tr/yayin-ve-kaynaklar/yasli-hizmetleri). The population of Turkey is 6.9\% disabled and 8.2\% is over 65 years old (Engelli ve Yaşlı Bireylere İlişkin İstatistiki Bilgiler,2017). It is assumed that supporting families with ICT, especially for those elderly people who need care to increase their access to services, will relieve the existing structure and reduce the costs of health and social care.

\section{TECHNOLOGY FOR ELDERS}

It is known that the utilisation of information and communication technology (ICT) in the World and in Europe is increasing day by day. There is a need to use ICT in our country and to make feasibility studies with potential knowledge. At the same 
time, the development of ICT-based products and supporting technological instruments is important for our country. There is a need for sectoral development to produce supporting technological products and products for smart homes. In this way, it is thought that both people who has different economic level will be able to access these products and long-term care (LTC) will be cost-effective. Because utilisation of technology in care services will optimise number of care staff's employment and simplify delivering of care services. For instance, with the purpose of improving and developing health at old age, regular health checks should be made at home on demand and there will be no transportation to hospitals costs. The model of home care service supported by technology for elderly people should have standards. Emergency call centers which has network with elderly people's home will be set up in order to provide emergency services to elderly people living at their own home. The system will be designed to operate through electronic assistance equipment that elder people who can live alone and no need formal care services live in their own home and social environment. Thus, instead of costly nursing homes for both government and individuals due to supportive technologies elder people can live in their home safely. In conclusion, promoting the use of ICT and ensuring sectoral development should be supported at all stages of are services. In this context, MoFSP is foreseen to make "Project of Utilisation of ICT in Care Services". The project is predicted to finish in 3 years.

\subsection{Utilization of Technology in Elderly Care Services}

During the first year of the project mentioned above, fairs and congresses will be visited annually to see technological developments that exist or have been made in relation to Care ICT on national and international platforms. As a result of these visits, it is aimed to organize fairs and congresses by the Ministry of Family and Social Policy for the selection of the technological products which are most suitable for my country and needy people. To exchange information with those who will participate in the fairs and congresses organised by project; individual negotiations of entrepreneurs who are willing to meet the needs of the needy will ensure that the existing problems can be reached more quickly and clearly, and the technology will provide them the solution will be more effective. Within the scope of these activities, this platform will be named as "ICT Platform for Care Services", where the NGOs convey their needs about elderly services to entrepreneurs. Entrepreneurs who has not fund can meet with angel investors because of this platform. In order to ensure the sustainability of the project; MoFSP, local authorities, associations or NGOs will develop criterias for ICT for care. If entrepreneur meets the criterias established by the Project, instead of grants, non-monetary incentive programs such as facility of gaining patents, invitation to relevant conferences, workshops and training, will provide them by competitions. It is ensured that the institutions or organizations included in the project are also members of the "ICT Platform for Care Services". To illustrate, R\&D studies that developed by young people who apply through university students or universities will compete for the idea of ICT in care and participate in the prototypes they have prepared. The rewards of this competition include non-monetary incentives. Through competition young entreprenurs can be recognised by sector and investors. Angel investors, the businessmen who invest in the money for young entreprenurs' ideas, can connect with entrepreneurs with this competition. Thus, at the end of mentioned project's activities will create awareness about market of care technologies in Turkey. Puclic sector should support and organise this kind of projects. Fairs, congresses, conferences and platforms will hold next first two years. During this period, NGOs interested in "ICT for Care Services" will focus on daily living activities will facilitate with technological care and they will come together with private sector and angel investors at local level. To see this in concrete terms, applications will be admitted in the designated pilot regions. In the first stage; big cities such as Ankara, Eskişehir and Mersin, and in the second stage other cities Adıyaman, Uşak, Kırıkkale and Sinop apply ICT in care. In this system; the data of the services performed will be collected in a database which will be formed within the Ministry of Family and Social Policy. This will ensure that the project will have a database with robust data in the years to come. Based on the existing database, it will be possible to find out where the use of technology that will be initiated with the project of "ICT use in care" is widely spread and the percentage of the elderly classified according to daily living activities and the percentage of the population according to the country rate will be recorded in a healthy manner and access easily. For example, there are "Elderly Living Homes" for elderly people in specific cities in Turkey, they can be made as smart home. After providing the ICT-based supportive technological equipment to these homes a short information about how to use technologies will be learned by caregivers and monitors will be settled in an institutions, namely nursing homes, rehabilitation centres. MoFSP Control room will evaluate care services regularly according to monitor records. In case of emergency, the technologic product will send signal to the control room and a staff from the nearest health center or health institution will be sent. In case of necessity, intervention will be done immediately. MoFSP, $\mathrm{MoH}, \mathrm{NGOs}$ and local governments will ensure the sustainability of their work by making a protocol between them. As a result of this work, it is expected that the care services transformation program will be accelerated so that the project outputs will be disseminated to ensure access to qualified and cost-effective care services. 


\section{DATA AND METHODOLOGY}

\subsection{Data}

The "World report on ageing and health 2015" emphasises that while some older people will require care and support, older populations in general are very diverse and make multiple contributions to families, communities and society more broadly (http://www.who.int/mediacentre/news/releases/2015/older-persons-day/en/) For this reason, using Information and Communication Technologies (ICT) in care services is an important issue that cost of care services can minimize by using this technologies in care. According to the Republic of Turkey Ministry of Family and Social Policies (MoFSP) Decree Law No. 633 dated 2011; there is a statement about strengthening of are services "establishing the necessary mechanisms, standardizing existing ones, monitoring and supervising the implementation of the social support for the elderly and the needy people with disabilities to live their lives without leaving their homes and their social environment". Moreover, "The Situation of Elderly People in Turkey and National Plan of Action on Ageing" of State Planning Organization mentions about encouraging development of convenient information technology, taking into consideration the changes that occur in physical qualities and seeing capacities of elderly people (State Planning Organization,2007). At the same time, the Turkish Active Aging Strategy Document-2017 is designed to support innovative approaches to facilitate the life of the elderly and to support research and development (R\&D) efforts to develop elderly friendly technologies.

Figure 1: Population of Turkey, 2013-2075 (TUiK, 2013)

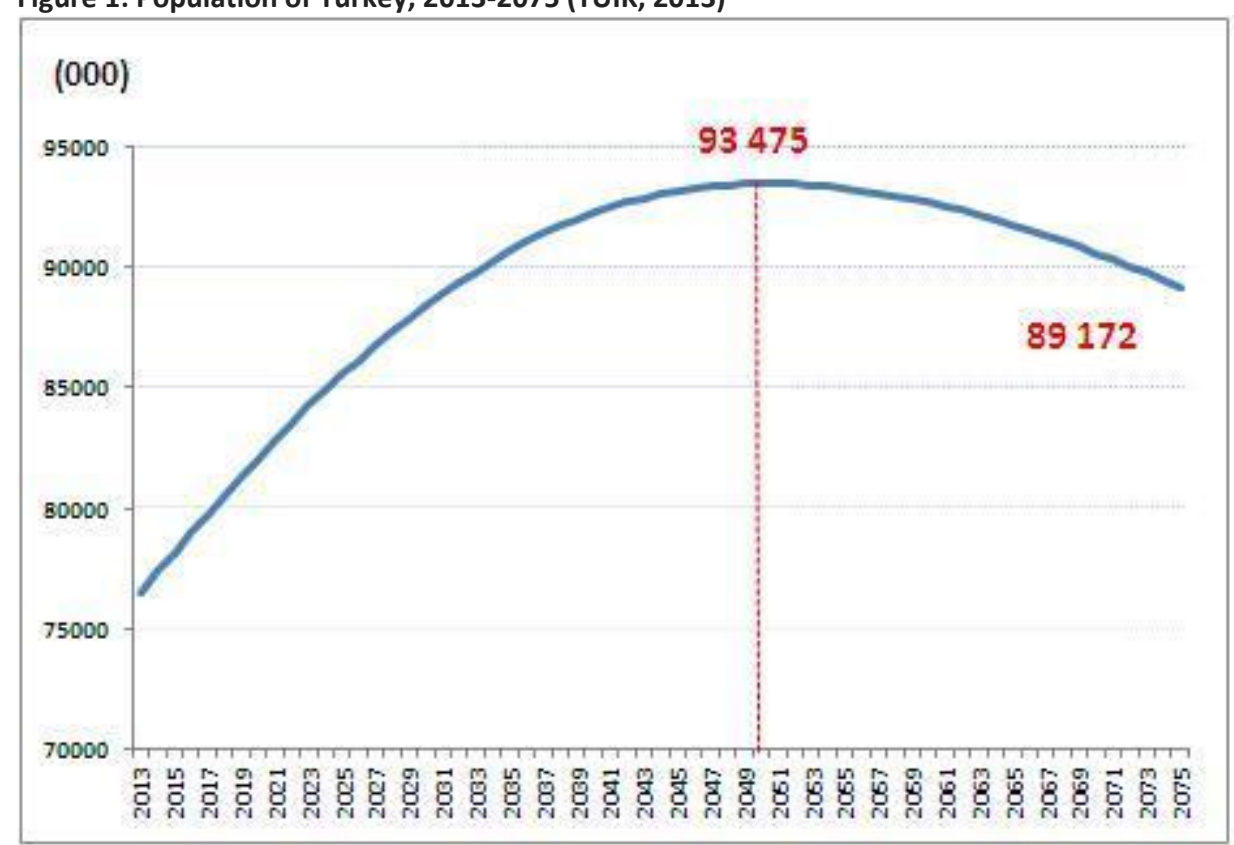

As seen figure 1, The population will increase slowly to the year 2050, and it will reach to its highest value with 93475575 people in this year. After 2050, the population will start to decline, and it is expected to be 89172088 in 2075 . If the current trends of demographic indicators persist, the population of Turkey will continue ageing. Elderly population, which is the population at 65 years of age and over, is 5.7 million in 2012 with a proportion of $7.5 \%$ and this population will reach to 8.6 million people with a proportion of $10.2 \%$ in 2023 (TÜiK,2013).

\subsection{Methodology}

After retirement, elderly people are pasive, they may have difficulty in moving or may have chronic diseases. Only nursing homes are not enough to respond to the growing elderly population. For this reason, it is necessary for cities and homes to be smart and care services should be supported with technology. 
Figure 2: eCAALYX's System Diagram

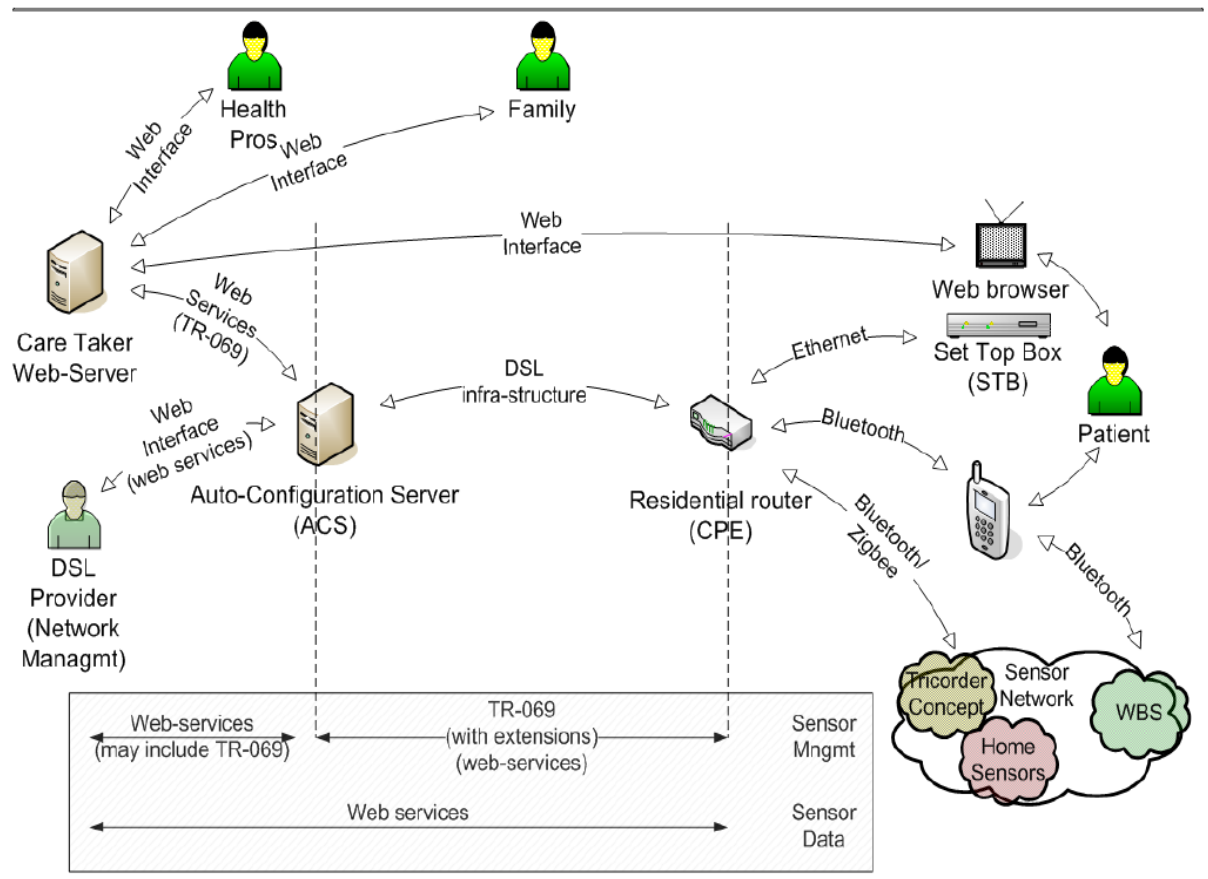

As seen figure 2, CAALYX (01/2007-12/2008 - http://caalyx.eu/) is a two-year eHealth project funded by the European Commission under FP6 (Sixth Framework Programme). It integrates the efforts of eight research, telecomm/industrial and end-user partners from six European countries, with the common goal of monitoring the health status of elderly users 24 hours a day, seven days a week, for the purpose of predicting/detecting any unfolding adverse health conditions and preventing complications (Boulos, Lou, Anastasios, Nugent, Alexandersson, Zimmermann, Cortes and Casas, 2009, p. 1951). A range of applications and services that could open up the healthcare market to a new generation of providers, such as home monitoring of the health status of the elderly and GPS-enabled phones to help Alzheimer's patients when they have wandered around or become disorientated, have been prototyped, and some of these solutions are currently being marketed to patients and their carers. Enabling wireless technologies, such as Bluetooth, have been shown to be enormously useful in data transmission over short distances from fixed or mobile devices. Frail pensioners needing round the clock care could well become among the routine users of Bluetooth wireless technology in the near future. Some vital signs monitoring systems have already been developed that send sensor data via Bluetooth to a personal computer, which can be consulted (even remotely) by a doctor or care workers, enabling them to keep an eye on the health of the patient and spot any problems before they become life-threatening (Boulos, Lou, Anastasios, Nugent, Alexandersson, Zimmermann, Cortes and Casas, 2009, p. 1969). As mentioned above such eHealth projects in Europe can be guide for Turkey. European countries has older population than Asian countries that Turkey can benefit from their experiences.

\section{FINDINGS AND DISCUSSIONS}

The Elderly Support Program (YADES) project is being implemented in order to improve the services at the local level in order to protect and support the elderly people who live in Turkey and who need services and to support those living in need of bio-psycho-social care (http://eyh.aile.gov.tr/uygulamalar/yasli-hizmetleri/yasli-destek-programi-yades-2016). Utilizing this experience of the institution; It is aimed to expand the use of ICT in home care (eg: smart home) in order to care for the level of care based on the daily activities of the individuals in need of care and to provide health care services in good quality and cost-effective. For this purpose, it is aimed to provide care service by using coordination center (nursing home, rehabilitation centres, family health center etc.) using the software to coordinate the care service. These softwares provide coordination between MoH, MoFSP, local governments and Non-Governmental Organizations (NGOs). At the same time telemonitoring, telecare, etc. supporting technological products should be established to support home care services. As an advice, within this scope, home care services should be organized in the coordination centers of MoFSP, which will be 
formed by MoH, local government and NGO protocols. These studies; Individuals in need of daily living activity should be provided by organizations providing home care services in accordance with procedures and standards.

In this context; congresses, fairs where national and international parties come together and share should be organised. The "ICT Platform for Care", where relevant parties are involved, should be established and sustainability should be ensured. These platform members; should be formed national and international actors such as entrepreneurs / angel investors, R\&Ds, techno-cities, NGOs, etc. For example, technological products such as home security systems, and easy-touse communication systems are increasingly used at every age and socio-cultural level. There are university techno parks and private sector entrepreneurs working in this field in Turkey. A small fraction of consumers are using ICT technologies in care, delivering health care to a small extent and delivering home care services. Joining innovative Approaches for the integration and Development of transnational Knowledge clusters policies related to independent living of Elderly (JADE) project supported by the EU has been carried out for 3 years since 2011. More than 30 institutions from 5 countries, including Turkey, Italy, England, France and Finland, worked together at the JADE Project where The Scientific And Technological Research Council Of Turkey (TUBITAK), İstanbul Metropolitan Municipality, Provincial Health Directorate participated in the leadership of Sabancı University in Turkey and 10 institutions from different sectors participated (http://www.ibb.gov.tr/sites/avrupa-birligi/abfonlari/Sayfalar/ABProjeler.aspx). With the JADE project, it is aimed to reveal the policies and methods that help the elderly to live healthy without needing them in the increasingly average society. Institutions from different countries involved in the project have prepared joint work plans to develop new and accessible technologies by bringing together R \& D centers. The target of new technologies to be developed; It aims to enable the elderly people to live their lives without having to depend on anyone and live a healthy and active social life.

\section{CONCLUSION}

To conclude, technological improvements for care will develop according to awareness of sector. With projects and studies about technologies for care services all actors in care services will meet with single platform "ICT Platform for Care Services". Applications, such as telomonitoring, telecare etc. from the coordination centers of home care services at the local level are expected to be supported by technological products and home care services. At the same time, the training of the people working in the public sector is strengthened and the contribution to the care services will be increased. Integration and monitoring of MoFSP, MoH, local governments and care services provided by NGOs (especially elderly care needs) will be provided. The quality of care services will be enhanced by strengthening local level care providers. On the other hand, the level of awareness of the care service quality in the community will also increase. At the national level, MoFSP, MoH, the "Integrated Family Information Database" system of local governments will be established. At the international level, good practice examples will be learned and shared. The national sector for care services will be strengthened by establishing grounds for international cooperation. At all levels, field studies for the utilisation of ICT in care services will be monitored, researched, implemented. The results will be evaluated according to protocols will be prepared.

\section{REFERENCES}

Boulos ,M. Lou, R. Anastasios, A. Nugent,C. Alexandersson,J. Zimmermann, G. Cortes U.,and Casas, R., 2009, Connectivity for Healthcare and Well-Being Management: Examples from Six European Projects. International Journal of Environmental Research and Public Health,6, 1948-1971.

Engelli ve Yaşlı Hizmetleri Genel Müdürlüğü, 2014. Bakım Hizmetleri Kalite Standardları. Access: http://kutuphane.aile.gov.tr/YayinDetay/Kitap/0727d289-b143-453e-987b-54d50a5c5b50. Access Date: 24.04.2017.

Engelli ve Yaşlı Hizmetleri Genel Müdürlüğü,2017. Engelli ve Yaşlı Bireylere İlişkin İstatistiki Bilgiler 2016 Yıl Sonu Raporu. Access: http://eyh.aile.gov.tr/data/551169ab369dc57100ffbf13/Bülten Ocak2017.pdf. Access Date: 24.04.2017.

Republic of Turkey Ministry of Family and Social Policies,2011. Decree Law No. 633. Access: http://www.mevzuat.gov.tr/Metin1.Aspx?MevzuatKod=4.5.633\&Mevzuatlliski=0\&sourceXmISearch=633\&Tur=4\&Tertip=5\&No=633 (Access Date: 24.04.2017)

State Planning Organization, 2007. The Situation of Elderly People in Turkey and National Plan of Action on Ageing. Access: http://www.monitoringris.org/documents/tools nat/trk.pdf (Access Date: 22.04.2017)

TÜiK, 2013. Population Projections, 2013-2075. News Bulletin of Turkish Statistical Institute, Number: 15844 , 14 February 2013. Turkish Statistical Institute, Ankara

YADES,2016. Access: http://eyh.aile.gov.tr/uygulamalar/yasli-hizmetleri/yasli-destek-programi-yades-2016. Access Date: 21.04.2017. 
World Report on Ageing and Health, 2015. Access: http://www.who.int/mediacentre/news/releases/2015/older-persons-day/en/. (Access Date: 24.04.2017)

(2011-2013) Kapsamında Bakım Hizmetleri Stratejisi ve Eylem Planı http://eyh.aile.gov.tr/yayin-ve-kaynaklar/yasli-hizmetleri ( Access Date: 23.04.2017)

http://www.ibb.gov.tr/sites/avrupa-birligi/abfonlari/Sayfalar/ABProjeler.aspx ( Access Date: 23.04.2017). 